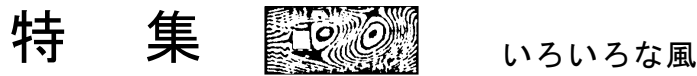

\section{水素ガス爆発による爆風 \\ Blast Wave Propagation of Hydrogen Explosion}

\author{
野津 剛*1 日比一喜*2
}

Tsuyoshi NOZU, Kazuki HIBI

\section{1。まえがき}

「低炭素社会の実現」に向けて燃料電池自動車 (FCV) および水素ステーション（FCVに水素ガスを供給する施 設）の普及が目指されており，水素ステーションの安全 性確保は重要な課題となっている $\left.\left.\left.{ }^{1)}, 2\right), 3\right), 4\right)$ 。特に, 水素 ガスは燃焼速度の速い物質であるため, 水素ステーショ ン内で漏洩水素に着火・爆発した場合，非常に強い爆風 圧が発生することが予測される。そのため，周辺一の爆 風圧の影響を確認するとともに，設備機器室の壁や防護 壁の破壊による飛散を防ぐために RC 壁の健全性につい ても確認する必要がある。

著者らは，防護壁に着目した水素ガスの爆発実験を実 施するとともに，これを対象とした爆風シミュレーショ ンおよび防護壁の応答シミュレーションについても実施 してきた ${ }^{5)}$,6)。ここに，その成果をまとめたものを紹介 する。なおここに紹介寸る一連の研究は新エネルギー・ 産業技術開発機構（NEDO）の「水素安全性利用等基盤 技術開発」事業として委託を受けて実施したものである。

\section{2. 爆発実験}

\section{1 爆発実験の概要}

爆発実験を実施した時の状況を図 1 に示す。水素濃度 $30 \%$ 空気との混合ガス $5.27 \mathrm{~m}^{3}$ をポリエチレンフィル
ムを用いたテント内に一様に充填させ，これに着火する ことにより爆発を発生させる。ガスの爆発現象には，燃 焼速度が音速以下の爆然（deflagration）と，音速を超え 衝撃波を伴う爆轟（detonation）とが知られている。屋 外では通常，爆然になるとされているが，半閉鎖空間や 障害物の影響を受けて爆然から爆轟へ遷移寸る現象 （DDT）が実験や CFD により明らかにされている4） 本爆発実験では，爆燃，爆轟のそれぞれの爆発現象を引 き起こすために，爆然実験では電気火花による着火を， 爆轟実験では爆薬による着火をおこなう。また，テント 端から $4 \mathrm{~m}$ （あるいは $2 \mathrm{~m} ）$ の距離に幅 $10 \mathrm{~m}$ ，高さ $2 \mathrm{~m}$,

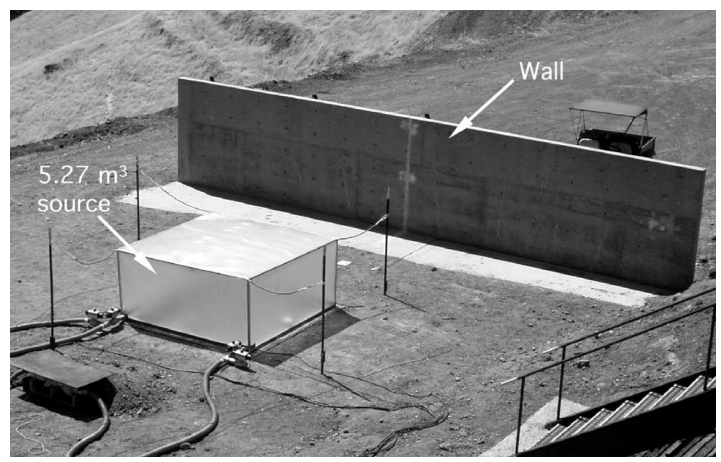

図 1 実験状況

* 1 清水建設 (株) 技術研究所 主任研究員

Senior research engineer, Institute of Technology, Shimizu Corporation.

* 2 清水建設 (株) 技術研究所リサーチフェロー

Research fellow, Institute of Technology, Shimizu Corporation. 
表 1 実験ケース

\begin{tabular}{|c|c|c|c|c|c|}
\hline Test & $\begin{array}{c}\text { Wall } \\
\text { Range }(\mathrm{m})\end{array}$ & $\begin{array}{c}\mathrm{H}_{2} \\
(\mathbf{\%})\end{array}$ & Ignition & $\begin{array}{c}\text { Temp. } \\
\left({ }^{\circ} \mathbf{C}\right)\end{array}$ & $\begin{array}{c}\text { Wind } \\
(\mathrm{m} / \mathrm{s})\end{array}$ \\
\hline Case1 & 4 & 30.0 & Spark & 27.2 & 2.2 \\
\hline Case2 & 4 & 30.0 & Explosive & 29.8 & 0.4 \\
\hline Case3 & 2 & 30.3 & Explosive & 22.4 & 1.3 \\
\hline
\end{tabular}

厚さ $0.15 \mathrm{~m}$ の鉄筋コンクリート造の防護壁を設置する。 実験ケースは表 1 に示すとおりである。

実験データの計測は，防護壁に埋め込んだ圧力センサ 一 (P2〜P7), 防護壁背面に設置した変位計 $(\mathrm{D} 1 ＼mathrm{~ D 6), ~}$ 鉄筋に貼つたひずみゲージ，地面上に設置した圧力セン サー（P1, P8, P9）を用いておこなった。防護壁面および 地表面の各センサーの設置位置を図 2 に示す。なお, 計 測のサンプリング時間は $1.0 \times 10^{-6} \mathrm{sec}$ である。
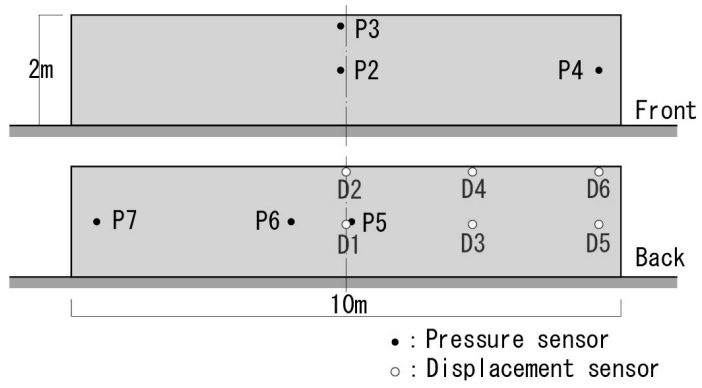

（a）防護壁面

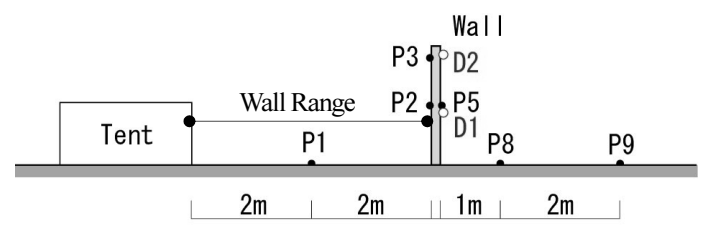

（b）地表面

図 2 圧力計および変位計の設置位置

\section{2 . 2 実験結果}

図 3 にCase1 (爆然) および Case2（爆轟）における 爆発実験のビデオ映像のフレーム写真を示す。テント (爆 心）から $100 \mathrm{~m}$ 以上離れた場所で実験の実施状況を見学 したところ, 爆然実験（Case1）では火炎を確認した後, 軽い風圧が感じられた。一方，爆轟実験（Case2）では 強い風圧を感じた後，大音響とともに地響きが生じ，土 埃が舞い上がるのが確認された。

困 4 に防護壁の表面の測定点 P2, 裏面の測定点 P5 に かかる爆風圧の時刻歴波形を力積（圧力の累積值）とと もに示す。爆燃（Case1）の場合は，防護壁の表・裏面
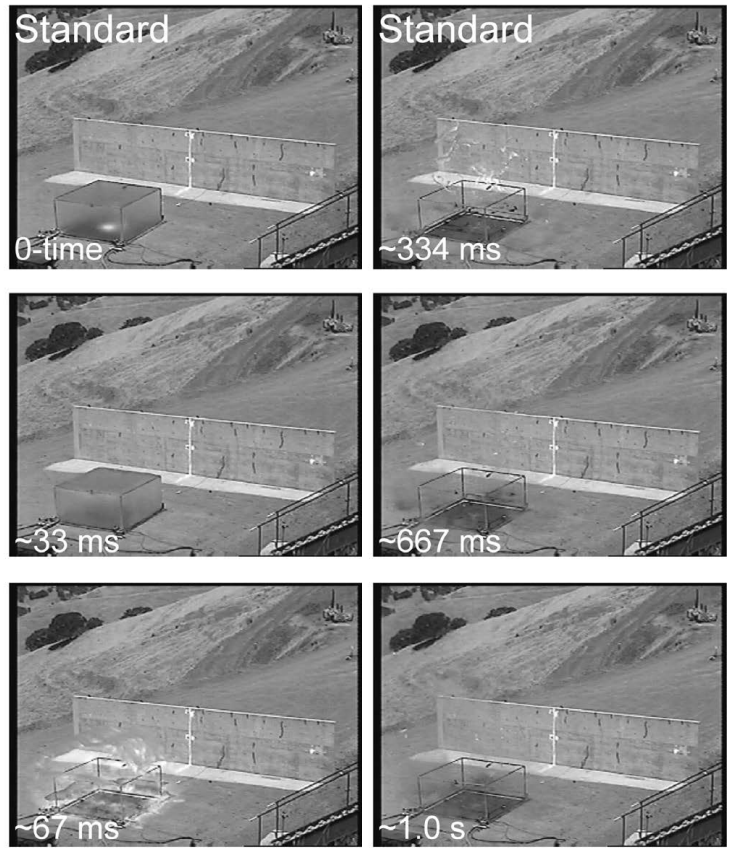

(a) 爆然実験（Case1）
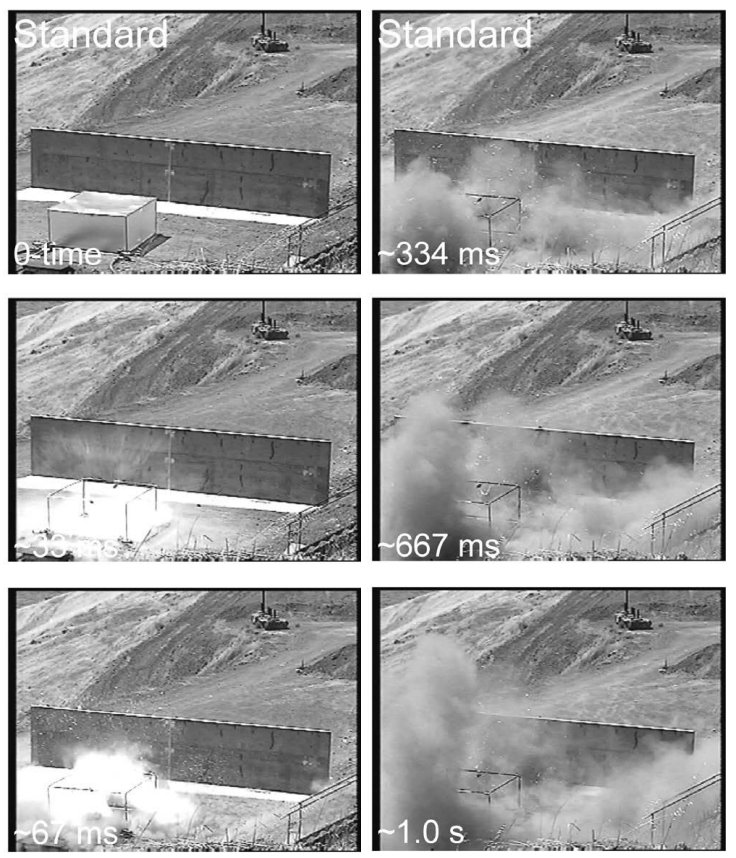

(b) 爆轟実験 （Case2）

図 3 爆発実験の高速ビデオ映像のフレーム写真

ともに正弦波に近い波形が得られており，緩やかに圧力 が上昇した後, 正圧よりやや強めの負圧へと転じている。 また，防護壁裏面の圧力は表面の圧力の $1 / 2 \sim 1 / 3$ 程度と 


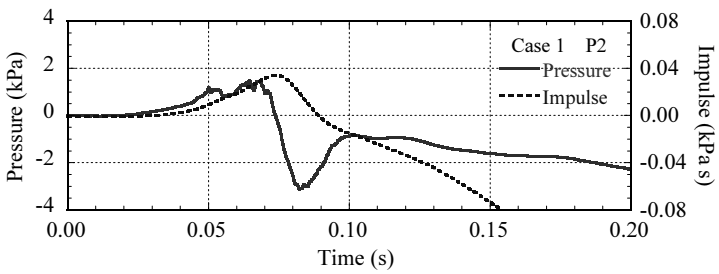

(a) 測定点 P2 (表面), 爆然

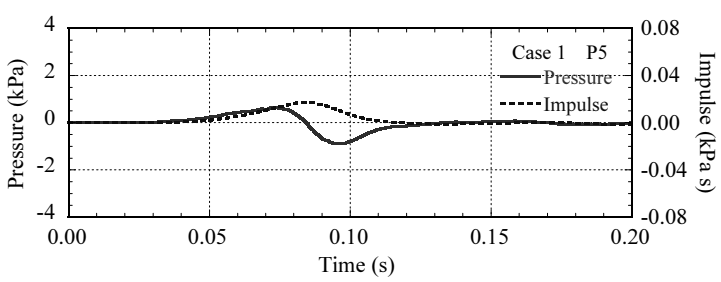

(b) 測定点 P5 (裏面), 爆然

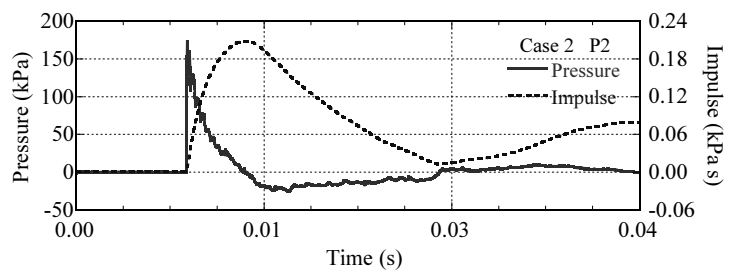

(c) 測定点 P2 (表面), 爆轟

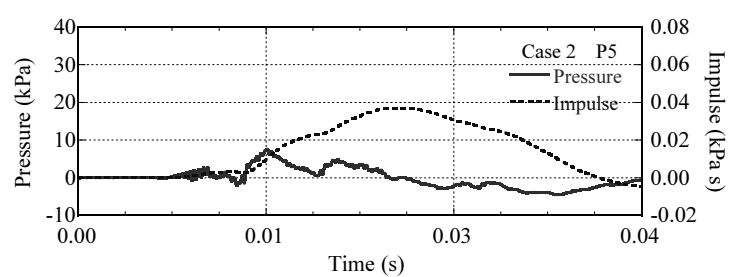

(d) 測定点 P5 (裏面), 爆轟

図 4 圧力および力積の時刻歴波形（左：Case1 (爆然)，右：Case2 (爆轟))

なっており，防護壁挙動を正確に把握する際には裏面の 圧力も無視し得ないほどの力を持っていると推測される。 一方，爆轟（Case2）の場合は，防護壁の表面では不連 続な立ち上がりの急峻な正のピーク值を取った後, 緩や かに負圧に移行しているが，防護壁の裏面では鋭いピー ク值はみられない。表面の圧力は爆然時の 100 倍程度と かなり大きくなっているが，正の圧力の作用時間は防護 壁の固有周期（約 $10 \mathrm{~Hz}$ ）と比べてかなり短く，防護壁の 応答は，爆風圧の絶対値よりも力積に支配されると予想 される ${ }^{7)}$ 。その力積は, 防護壁の表面では爆然時の 6 倍 程度に止まっている。また，爆轟時の防護壁の表面と裏 面の圧力差が非常に大きいことが確認される。

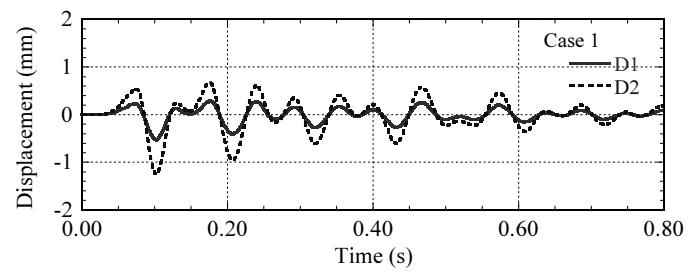

(a) 爆然 (Case1)

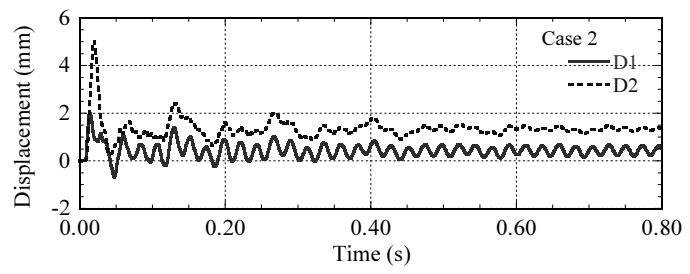

(b) 爆轟（Case2)

図 5 測定点 D1，D2 の応答変位の時刻歴波形
図 5 に防護壁の中心部の測定点 $\mathrm{D} 1, \mathrm{D} 2$ の応答変位の 時刻歴波形を示す。爆然（Case1）の場合は，防護壁の 1 次の固有周期で振動している様子が確認できる。一方, 爆轟時 (Case2) の変位は, 爆然時の 5, 6 倍程度であり, 力積は防護壁の挙動に対して支配的であることを裏付け ている。また，応答波形から高次の振動モードで摇れて いることも確認できる。

図 6 に離隔距離とピーク圧力との関係を既往の実験結 果 ${ }^{2)}$ とともに示寸。それぞれの爆発形態によって，ほぼ 一直線上にプロットされることが確認できる。また，爆 轟は爆然と比べて爆心近傍場で 2 オーダー，遠方場で 1 オーダー圧力が大きくなっている。さらに，防護壁の効 果は, 爆轟の場合の方がより効果的であることがわかる。

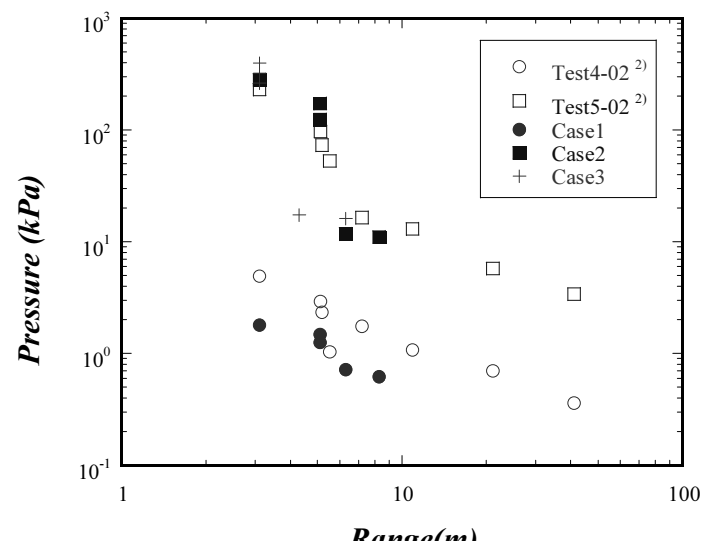

Range(m)

図 6 離隔距離とピーク圧力の関係 


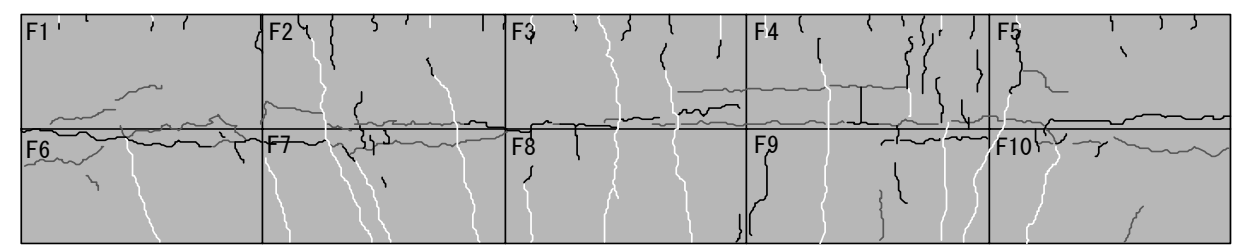

（a）防護壁表面

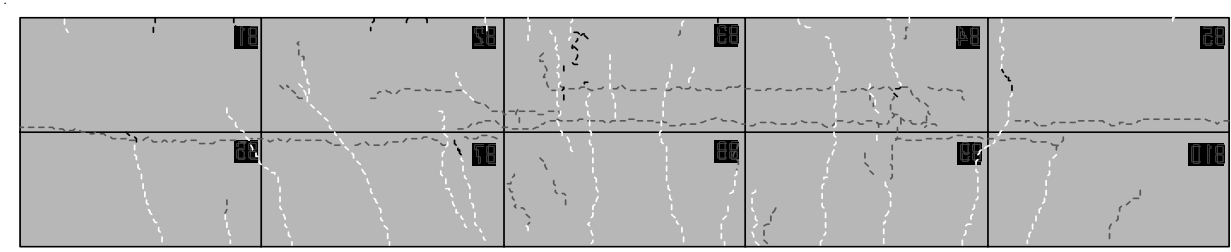

(b) 防護壁裏面

図 7 爆発実験後のひび割れ分布図

図 7 に実験後の防護壁のひび割れ状況を示す。爆轟実 験後にひび割れが発生している様子が確認できる。ひび 割れは防護壁高さの $1 / 2$ の高さで水平に生じていること がわかる。

\section{3. 数值シミュレーション}

2. で実施した爆発実験について，爆風伝播状況およ び防護壁の変位挙動を把握するため, 数值シミュレーシ ヨンを実施する。

\section{1 数值解析の概要}

爆風圧の計算は，3 次元圧縮性オイラ一方程式を用い る。計算領域 $22 \mathrm{~m} \times 20 \mathrm{~m} \times 12 \mathrm{~m}$ の解析空間をとり，壁面 上に作用する爆風圧の時刻歴波形を求めた。解析空間は 図 8 に示すとおりである。計算格子は $221 \times 201 \times 61$, $\Delta \mathrm{x}=\Delta \mathrm{y}=0.1 \mathrm{~m}, \Delta \mathrm{z}=0.2 \mathrm{~m}$ の等間直交隔格子を用い，時 間刻夕は，爆然時 (Case1) は $\Delta \mathrm{t}=2.35 \times 10^{-4} \mathrm{sec}$, 爆轟

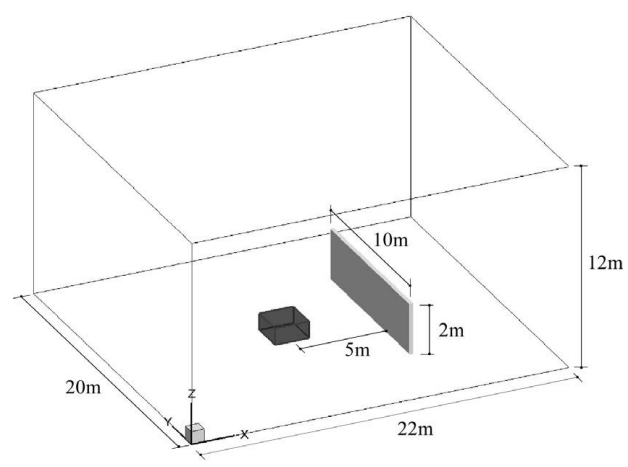

図 8 解析空間
時（Case2 およびCase3）は $\Delta \mathrm{t}=5.88 \times 10^{-5} \mathrm{sec}$ とした。 なお，本解析では燃焼解析を行っていないため，火炎伝 播速度が大きい爆轟では, 最初の計算ステップに燃焼に よって発生する全てのエネルギーが放出されるものとし， また，火炎伝播速度が比較的小さい爆然に対しては燃焼 によるエネルギーをある時間幅で緩やかに放出させるも のとした6)。

防護壁の応答計算は, 有限要素法による汎用構造解析 システム DIANA（TNO 社）により実施した。解析モデ ルは, 左右の対称性を考慮して $1 / 2$ モデルとして脚部は 固定条件とする。四角形 $(200 \mathrm{~mm} \times 200 \mathrm{~mm})$ のシェル を用いた有限要素モデルとして，コンクリート部は厚さ 方向に 9 点の積分点を設け, 鉄筋は実断面積と等価な面 積を持つシェル要素として鉄筋位置に配置した。ここで 用いる材料特性は，材料試験結果により設定したコンク リート及び鉄筋の復元力特性を用いている ${ }^{8)}$ 。なお，外 力は爆風伝播解析から得られた防護壁の表面及び裏面の 圧力の時刻歴データを用いる。時間刻みは $0.5 \mathrm{~ms}$ ，時間 積分はNewmark- $\beta$ 法とした。

\section{2 解析結果}

図 9 にCase2 を対象とした爆風伝播解析による圧力コ ンターおよび圧力等值面の時間変化を示す。爆発直後で は，爆風圧（衝撃波）は半球状に急激に広がり，防護壁 に到達すると，防護壁面上で反射・回折が生じている。 防護壁前面では強い正圧のすぐ直後に周囲よりも強い負 圧が発生しており，防護壁近傍では複雑な分布性状にな っている。また，爆風圧は空間的に広がるにつれ，急激 


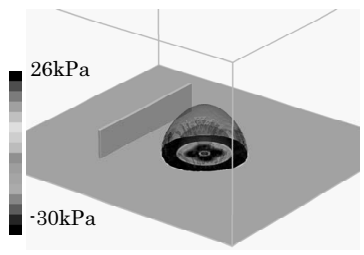

(1) $\mathrm{t}=0.0035 \mathrm{~s}$

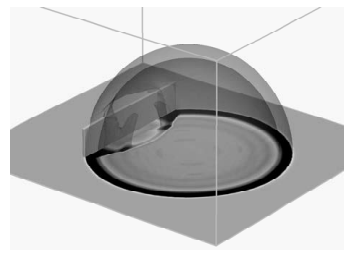

(3) $\mathrm{t}=0.0117 \mathrm{~s}$

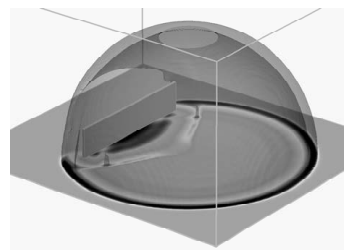

(5) $\mathrm{t}=0.0158 \mathrm{~s}$

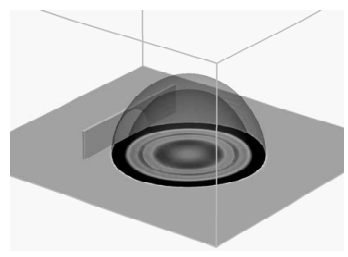

(2) $\mathrm{t}=0.0076 \mathrm{~s}$

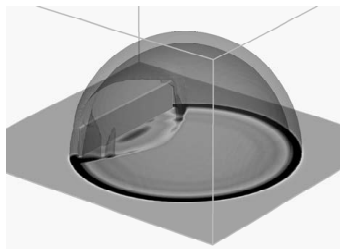

(4) $\mathrm{t}=0.0137 \mathrm{~s}$

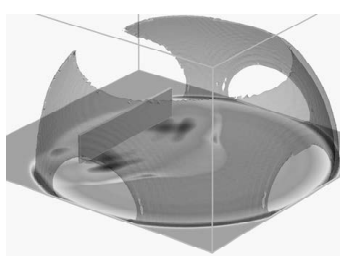

(6) $\mathrm{t}=0.0199 \mathrm{~s}$
図 9 爆轟時（Case2）の圧力および等值面の時間变化

に圧力が低下している様子も確認できる。

図 10, 図 11 に防護壁面（P2, P4, P5, P7）にかかる爆 風圧の時刻歴波形を示寸。爆然，爆轟ともに防護壁の表 面または裏面の中心部と端部といった測定位置の違いに よる時間ずれなど実験結果を良く再現している。特に Case2 において, 防護壁裏面の測定点P 7 では, 爆心位 置に近い P5 よりも圧力が高くなる現象が実験で得られ ているが, 数值解析でも再現できていることが確認でき る。これは，防護壁の上部を回折する波と，側面を回折 する波とが重なることに起因する。

防護壁の応答変位の時刻歴波形を爆発実験結果と数值 計算結果とを比較して図 12 , 図 13 に示す。Case1では 3 波目辺りで位相のずれが若干見られるが，振幅值は良 く一致している。一方, Case2 は最初に作用する衝撃的 な圧力波による応答変位を良く捕らえており, 実験結果 に見られるドリフトを考慮すれば，壁の挙動を良く再現 していると言える。

Case2 の数值解析による防護壁表側のコンクリートひ ずみと変位状況を図 14 に示す。図中の色の濃い部分はひ び割れの発生するひずみレベルである。解析結果による と, 防護壁の脚部と $1 / 2$ 高さで水平方向にひび割れが発 生しているが, 爆発実験では, 防護壁脚部のひび割れが
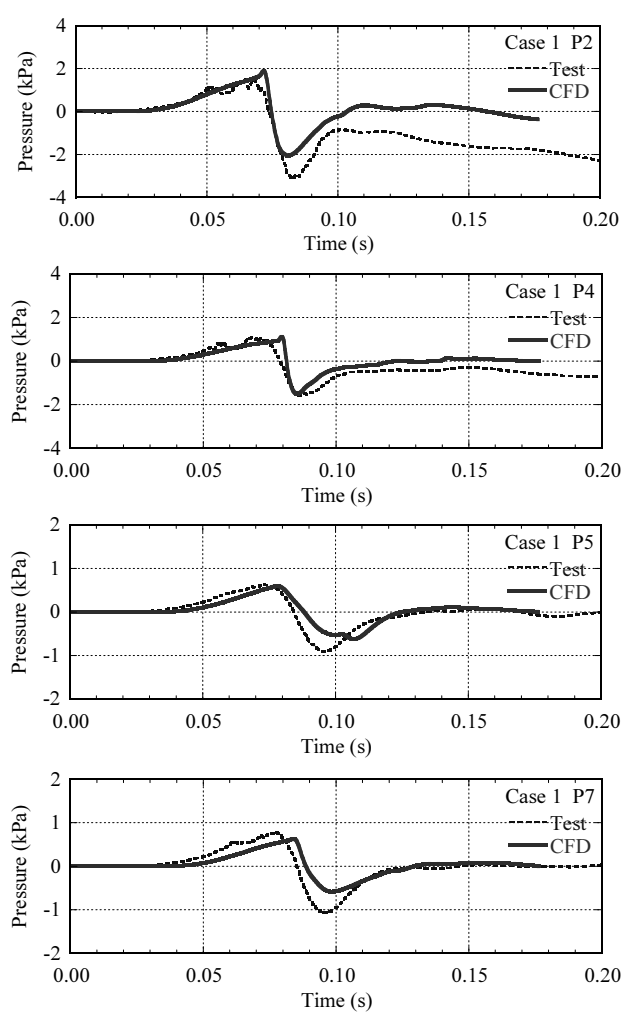

図 10 爆然時（Case1）の圧力の時刻歴波形
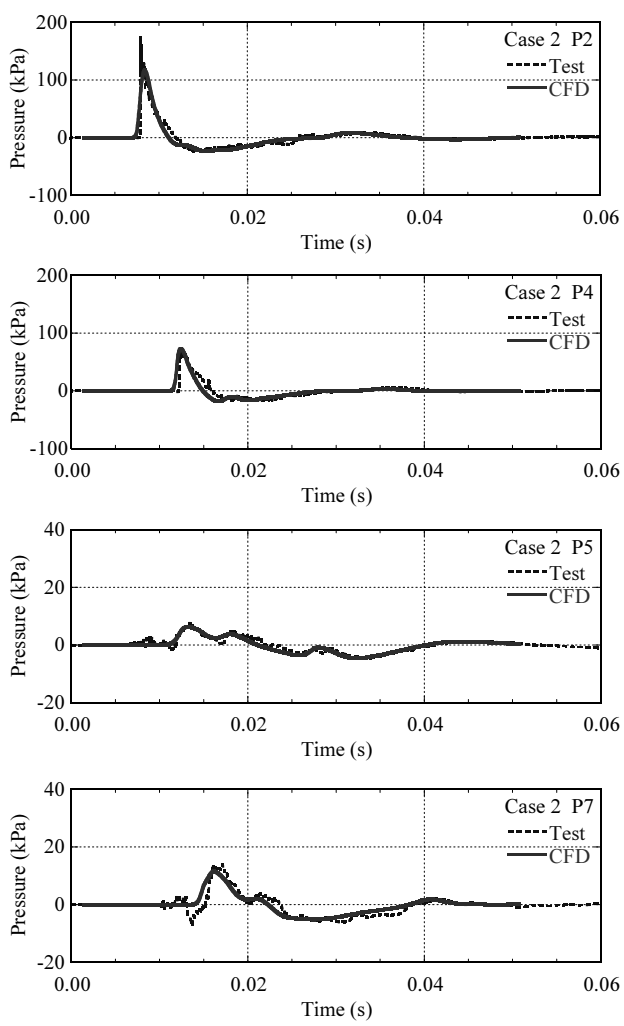

図 11 爆轟時（Case2）の圧力の時刻歴波形 

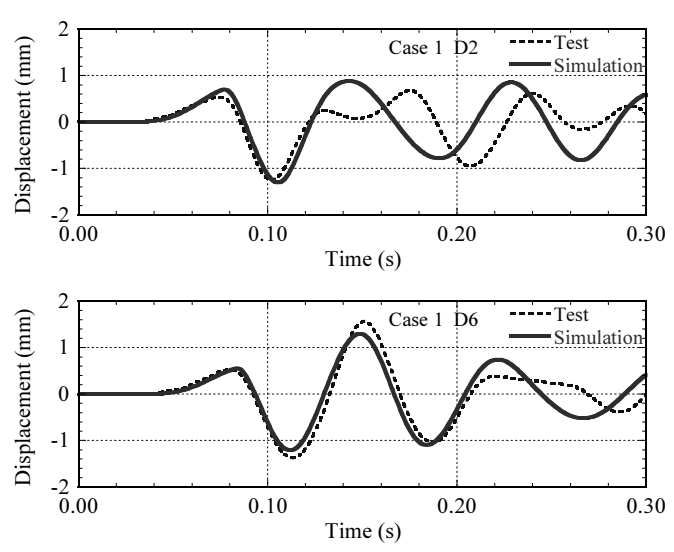

図 12 爆然時 (Case1) の防護壁の応答変位 $(\mathrm{D} 2, \mathrm{D} 6)$
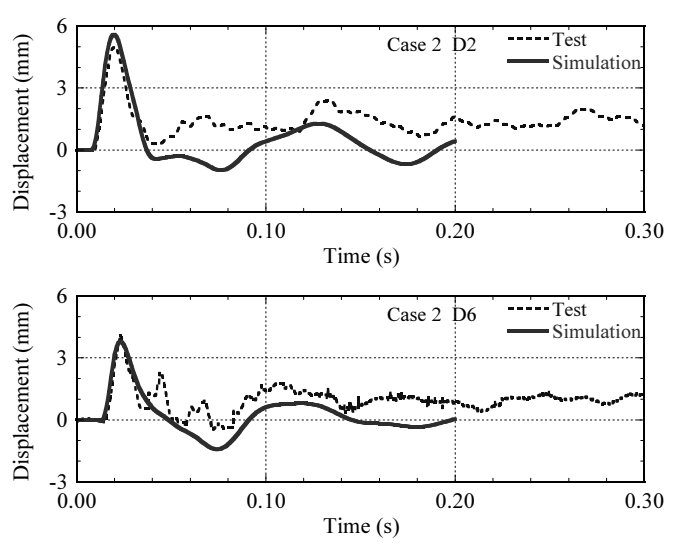

図 13 爆轟時 $(\mathrm{Case} 2)$ の防護壁の応答変位 $(\mathrm{D} 2, \mathrm{D} 6)$

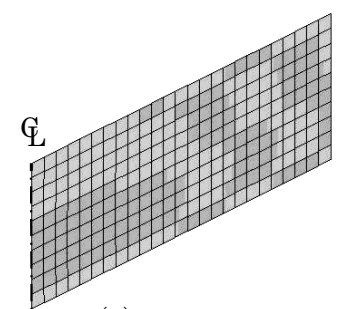

(1) $\mathrm{t}=0.004 \mathrm{~s}$

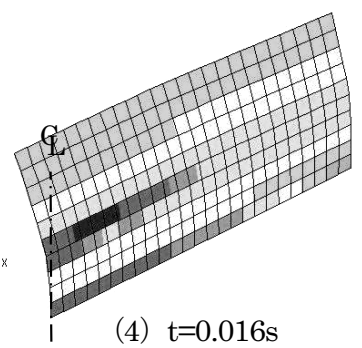

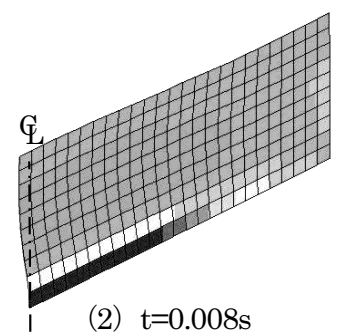

(2) $\mathrm{t}=0.008 \mathrm{~s}$

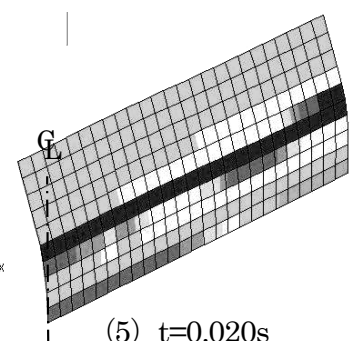

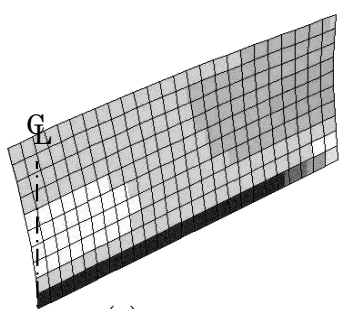

(3) $\mathrm{t}=0.012 \mathrm{~s}$

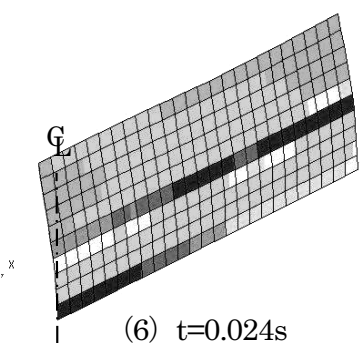

I. $5 \mathrm{E}-3$

1. $4 \mathrm{E}-3$

1. $3 \mathrm{E}-3$

$.2 \mathrm{E}-3$

$.1 \mathrm{E}-3$

$-.582 \mathrm{E}-1 \mathrm{~B}$

(1-. $-1 \mathrm{E}-3$

$\square-.2 \mathrm{E}-3$

$1-.3 \mathrm{E}-3$

$-.4 E-3$

$-.5 \mathrm{E}-3$

図 14 爆轟時（Case2）における防護壁表面のコンクリートひずみと変位挙動の時間変化

ほとんど観察されなかった。この要因として, 鉄筋の密 度が低いことなどから，実験では固定端となっていなか ったためと推察される。

\section{5。まとめ}

爆発実験を実施するとともに，数值シミュレーション により爆発実験を再現した。爆然，爆轟という燃焼形態 の異なる場合の壁面に働く爆風圧の時刻歴波形など，初 期条件をうまく与えることで, 精度良く評価できること を確認した。また，衝撃的な爆風圧が壁に作用した場合 でも，爆風圧を精度良く再現できれば，応答計算により 壁の挙動を精度良く評価できることを確認した。

\section{参考文献}

1）平成 14 年度 NEDO 成果報告書「水素利用国際クリーン エネルギーシステム技術（WE-NET）第 II 期研究開発，
タスク 2 安全対策に関する調查・研究」, NEDO-WE-NET-0202, 平成 15 年 3 月

2) Groethe, M., Colton, J., Chiba, S. and Sato, Y., "Hydrogen Deflagrations at Large Scale", $15^{\text {th }}$ World Hydrogen Energy Conference, 2004.

3）平成 15 年 平成 16 年度 NEDO 成果報告書「水素安全利 用等基盤技術開発一水素インフラに関寸る研究開発一水 素インフラに関する安全技術研究」, 平成 17 年 3 月

4）清水建設, 米海軍研究所, 成蹊大学, NEDO 水素に関寸 る共通基盤技術開発一国際共同研究，2006.

5) Nozu, T.,Tanaka, R., Ogawa, T., Hibi, K. and Sakai, Y., International Conference on Hydrogen Safety (ICHS), 2005

6）野津，日比，小川, 「水素爆発による爆風シミュレーショ ン」, 第 18 回 風工学シンポジウム, 2004

7）梅村, 松島, 「衝撃に対する一質点の線径応答」, 日本建築 学会論文報告集，第 103 号，1964

8) 酒井, 稲葉, 野津, 小川, 「水素安全利用に関する研究 (そ の2）防護壁の応答シミュレーション」, 日本建築学会大 会, 2005 